\title{
MOLECULAR DETECTION OF HPV 16 AND 18 IN CERVICAL SAMPLES OF PATIENTS FROM BELO HORIZONTE, MINAS GERAIS, BRAZIL
}

\author{
Taíse Palmeiras FREITAS(1), Bianca Bianco do CARMO(1), Francisco Danilo Ferreira PAULA(1), Lucas Fonseca RODRIGUES(2), \\ Ana Paula FERNANDES(2) \& Paula Ávila FERNANDES(2)
}

\begin{abstract}
SUMMARY
Purpose: The aim of this study was to investigate the frequency of HPV infection and the types 16 and 18 in cervical samples from patients attended at two public health services of the city of Belo Horizonte, MG. Methods: Cervical samples from 174 patients were collected for cytopathological and molecular tests. HPV infection was searched by PCR utilizing MY09 and MY11 primers or HPV 16 and HPV 18 specific primers. Results: Amongst the 174 samples analyzed, 20.7\% presented squamous intraepithelial and/or invasive lesions detected on cytopathological analysis and of those, 94.4\% were infected by HPV. HPV 16 was found in $20 \%$ of the cases of low-grade squamous intraepithelial lesions and in $40 \%$ and $50 \%$ of high-grade squamous intraepithelial lesion and squamous invasive carcinoma, respectively. HPV 18 was detected in $6.7 \%$ of the low-grade lesion samples and in two HPV16 co-infected samples. In 50\% of the cases of high-grade lesion, the HPV type was not determined. Conclusion: The HPV 16 was the virus type more frequently detected. However, more than $50 \%$ of the positive samples at the cytopathological analysis were negative for HPV 16 and 18, indicating that possibly other virus types are present in relative high frequencies in the studied population.
\end{abstract}

KEYWORDS: HPV; Cervical cancer; PCR; Genotyping; Cytology.

\section{INTRODUCTION}

Cervical cancer is one of the most frequent diseases in women and a considerable cause of morbidity and mortality among them. It is the second more frequent type of cancer in women worldwide, preceded only by breast cancer ${ }^{11,28}$. In Brazil, it is estimated that cervical cancer is the third more common type of malignant neoplasia and the fourth cause of death by cancer among women. It was estimated the occurrence of 19260 new cases of cervical cancer in 2006 in Brazil ${ }^{4}$.

Cervical cancer is closely related to persistent infection by highrisk Human Papillomaviruses (HPV) ${ }^{28}$. In a study performed on cervical biopsy samples from patients of 22 countries, HPV DNA was detected by polymerase chain reaction (PCR) in $99.7 \%$ of the cases of cervical cancer, indicating that HPV is in fact the main cause of this type of cancer $^{18}$. On the other hand, the HPV detection rate in patients with no cervical epithelial abnormalities varies from $5 \%$ to $20 \%{ }^{8,15,24}$.

In Brazil, a prevalence of HPV infection ranging from $15 \%$ to $27 \%$ have been detected by hybrid capture (HC) or PCR in studies performed in health services for screening cervical cancer ${ }^{16,20}$. However, in patients with cervical cancer, HPV DNA detection has ranged from $55.2 \%$ to $91 \%$, depending on the type of biological material and method used $^{3,7,10,12,17,21}$.
The most prevalent types of high-risk HPVs that infect the uterine cervix are: HPV 16 (53\%), HPV 18 (15\%), HPV 45 (9\%), HPV 31 $(6 \%)$ and HPV $33(3 \%)^{18}$. According to studies performed on the Brazilian population, HPV 16 is the most frequent type found in all regions of the country, though there is an important variation regarding the frequency of infection by other types. Accordingly, HPV 18 is the second most prevalent in North, South and Southeast regions. HPVs 31 and 33 correspond to the second most prevalent type in the Northeast and Central regions, respectively $3,10,17,21,22$.

Specific HPV types present different relative risks for the development of cervical cancer ${ }^{6,14}$. Thus, HPV typing is important for the prognosis of epithelial lesions in uterine cervix. Besides, the identification of HPV types that are more commonly associated to cervical cancer in different regions may help in strategies for cancer prevention, including the development and efficacy evaluation of effective vaccines. In this study, the molecular detection of HPV and the types 16 and 18 was performed in cervical samples from patients who attended at two public health services in Belo Horizonte.

\section{MATERIAL AND METHODS}

This study was performed prospectively by obtaining cervical samples from patients attended at secondary public health services in

Financial support: Authors thank FAPEMIG (CDS 206/04) and CNPq (48034/04-2) for financial support.

(1) Programa de Pós-Graduação em Ciências Farmacêuticas da Faculdade de Farmácia da UFMG, Belo Horizonte, MG, Brasil.

(2) Departamento de Análises Clínicas e Toxicológicas da Faculdade de Farmácia da UFMG, Belo Horizonte, MG, Brasil.

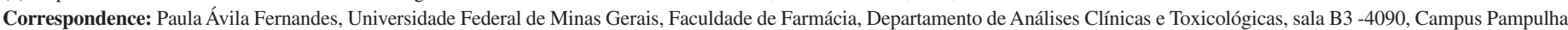
Avenida Antônio Carlos 6627, 31270-901 Belo Horizonte, Minas Gerais, Brasil. Phone: +55.31.3499-6879, Fax: +55.31.3499-6985. E-mail: paulafernandes@ufmg.br 


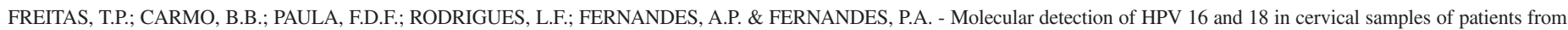
Belo Horizonte, Minas Gerais, Brazil. Rev. Inst. Med. trop. S. Paulo, 49(5): 297-301, 2007.

Belo Horizonte. The cervical samples collected from 174 patients were submitted to cytopathological analysis and molecular tests for HPV detection, searching for HPVs 16 and 18.

The patients selected for this study were refered to secondary public health services for further investigation, since cytopathological or colposcopic abnormalities were previously detected during the clinical or cytopathological analysis at primary public health services. The results of the cytopathological analysis performed at the primary public health services were not reviewed by the authors in the present study.

Information concerning the research was provided to all participants with a simple and clear language. After the explanation, a clinical form was filled and all the participants signed a free and informed consent approved by the institutional ethic committee of Universidade Federal de Minas Gerais.

The cervical samples were collected by gynecologists utilizing the liquid-based cytology technique (DNA Citoliq ${ }^{\circledR}$ DIGENE). DNA extraction was carried out in aliquots obtained from the frozen samples in liquid medium, using the protocol described by VILLA et al. ${ }^{29}$, with modifications. DNA extraction was performed from $200 \mu \mathrm{L}$ of the cell suspension. Cells were centrifuged at 3,000 rpm for five min. and the sediment obtained was suspended in $400 \mu \mathrm{L}$ of a cell lysis solution and centrifuged at 10,000 $\mathrm{rpm}$ for five min. This procedure was repeated until a white pellet with no traces of hemoglobin has been obtained. The pellet was then suspended in $300 \mu \mathrm{L}$ of cell lysis solution containing SDS $0.5 \%$ and proteinase $\mathrm{K}$ to a final concentration of $0.05 \mathrm{ng} / \mathrm{mL}$ and incubated at $56{ }^{\circ} \mathrm{C}$, during one hour and afterwardst for $10 \mathrm{~min}$ at $95^{\circ} \mathrm{C}$ for denaturation. DNA was then precipitated by addition of ammonium acetate $(1.4 \mathrm{mM})$ and an equal volume of iced isopropanol and centrifugation at $10,000 \mathrm{rpm}$ for $15 \mathrm{~min}$ at $4{ }^{\circ} \mathrm{C}$. The pellet was washed with iced $95 \%$ ethanol and centrifuged at $14,000 \mathrm{rpm}$ for $10 \mathrm{~min}$ at $4{ }^{\circ} \mathrm{C}$. The pellet was dried and suspended in $100 \mu \mathrm{L}$ of Tris $(10 \mathrm{mM})$ and EDTA $(1 \mathrm{mM})$.

The smears were stained by Papanicolaou method, examined randomly, without knowledge of the results of molecular tests and classified according to the Bethesda System. The samples showing atypical squamous or glandular cells of undetermined significance (ASCUS and/or AGUS), squamous intraepithelial lesion (SIL) and/or invasive carcinoma were considered positive. The samples showing a normal pattern and inflammatory and/or reactive changes were considered negative.

All samples were submitted to a PCR reaction with PC03/PC04 primers that amplify a $110 \mathrm{pb}$ fragment of the human $\beta$-globin gene, as an inner control, to verify the integrity and quality of the DNA extracted $^{25}$. The PCR reaction consisted of $0.05 \mathrm{mM}$ of each dNTP; 1 UI of Taq polymerase; $1.5 \mathrm{mM}$ of $\mathrm{MgCl}_{2} ; 0.5 \mathrm{pmol} / \mu \mathrm{L}$ of each primer and $1.0 \mu \mathrm{L}$ of the extracted DNA. PCR conditions comprised thirtyfive amplification cycles, performed in thermal cycles (MJ Research), of denaturation for 1.0 minute at $94{ }^{\circ} \mathrm{C}$, annealing for 1.0 minute at $55^{\circ} \mathrm{C}$ and extension for 1.0 minute at $72{ }^{\circ} \mathrm{C}$.

All samples were then searched for HPV infection by PCR with the MY09/11 consensus primers. Negative samples at the MY09/11 evaluation and positive $(n=16)$ or negative $(n=20)$ in cytological analysis were submitted to an additional PCR reaction with the GP5+/ GP6+ consensus primers. The MY09/11 primer set amplifies a sequence of 450 pairs of basis (pb), whereas GP5+/GP6+ amplifies a $150 \mathrm{pb}$ fragment of the L1 HPV genomic region ${ }^{1,23}$. PCR conditions for both primer sets comprised forty cycles of denaturation for 1.0 minute at $94{ }^{\circ} \mathrm{C}$, annealing for 1.0 minute at $56{ }^{\circ} \mathrm{C}$ (MY09/11 primers) or at 45 ${ }^{\circ} \mathrm{C}$ (GP5+/GP6+ primers) and extension for 1.0 minute at $72{ }^{\circ} \mathrm{C}$. When HPV was detected, additional PCR reactions were carried out using primers that are specific for HPV types 16 and 18 and amplify DNA fragments of 152 and $216 \mathrm{pb}$, respectively ${ }^{13}$. PCR conditions were similar to those used for MY09/11 or GP5+/GP6+ primers sets, except that annealing was performed at $57^{\circ} \mathrm{C}$ for the HPV-16 specific primers and at $65{ }^{\circ} \mathrm{C}$ for the HPV-18 specific primers. The viral type was considered not determined (HPV-X) in HPV positive samples when neither DNA-HPV 16 nor DNA-HPV 18 were amplified, since only these HPV types were investigated in the present study.

PCR reaction products, along with molecular weight standards, were submitted to $6 \%$ polyacrilamide gel electrophoresis and silver staining. In all PCR reactions a positive control was included which consisted of a previously known HPV positive sample. A negative control was also included which contained all the reagents except DNA.

\section{RESULTS}

Among the samples analyzed, $79.3 \%$ (138/174) were negative in the cytopathological analysis; $5.2 \%(9 / 174)$ presented ASCUS/AGUS; $8.6 \%(15 / 174)$ presented low-grade squamous intraepithelial lesion (LSIL); $5.7 \%$ (10/174), high-grade squamous intraepithelial lesion (HSIL) and $1.1 \%(2 / 174)$, invasive epidermoid carcinoma.

HPV infection was detected in $39.6 \%$ (69/174) of the samples by PCR technique. Initially, it was observed that some samples with positive results at the cytopathological analysis did not present HPV DNA in PCR reactions with primers MY09/11. These samples ( $\mathrm{n}=$ 16) were, then, submitted to new PCR reactions with primers GP5+/ GP6+. Twelve out of these 16 analyzed samples (75\%) showed HPV DNA, allowing the detection of an increased HPV infection rate $(35.1 \%)$.

Samples that were simultaneously negative in cytopathological analysis and PCR using MY09/11 primers $(\mathrm{n}=20)$ were also submitted to PCR with GP5+/GP6+ primers. Of those, 6 (30\%) were DNA-HPV positive in this later analysis.

Considering the cytopathological positive samples, 94.4\% (34/36) presented HPV DNA. In those samples which HSIL or invasive carcinoma were detected, 100\% were HPV-positive in PCR testing, whereas among the cytopathological negative samples, $25.4 \%$ were HPV-positive (Table 1). In general, the detection rate for HPV infection was higher as the severity of the lesions increased.

The results for viral typing are presented in Table 2 . HPV 16 was found in $22.2 \%$ of the samples of ASCUS/AGUS, in $20 \%$ of samples of LSIL, in $40 \%$ of samples of HSIL and in $50 \%$ of the invasive carcinoma. HPV 18 was found in $6.7 \%$ of the samples with LSIL and in $2.2 \%$ of the negative samples. Co-infection was found in two samples. Since DNA-HPV was detected in all the HSIL and invasive carcinoma 


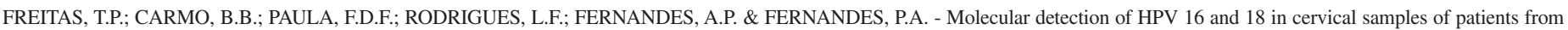
Belo Horizonte, Minas Gerais, Brazil. Rev. Inst. Med. trop. S. Paulo, 49(5): 297-301, 2007.

Table 1

Results of cytopathological and molecular analyses in 174 cervical samples

\begin{tabular}{|c|c|c|c|c|c|}
\hline \multirow[t]{2}{*}{ Cytology } & \multicolumn{2}{|c|}{ HPV-DNA Negative } & \multicolumn{2}{|c|}{ HPV-DNA Positive } & \multirow[t]{2}{*}{ Total } \\
\hline & $\mathrm{n}$ & $\%$ & $\mathrm{n}$ & $\%$ & \\
\hline Negative & 103 & 74.6 & 35 & 25.4 & 138 \\
\hline ASCUS/AGUS ${ }^{\mathrm{a}}$ & 1 & 11.1 & 8 & 88.9 & 9 \\
\hline LSIL $^{\mathrm{b}}$ & 1 & 6.7 & 14 & 93.3 & 15 \\
\hline $\mathrm{HSIL}^{\mathrm{c}}$ & - & - & 10 & 100 & 10 \\
\hline Invasive carcinoma & - & - & 2 & 100 & 2 \\
\hline Total & 105 & & 69 & & 174 \\
\hline
\end{tabular}

a: ASCUS/AGUS: Atypical squamous or glandular cells of undetermined significance; b: LSIL: Low grade squamous intraepithelial lesion; c: HSIL: High grade squamous intraepithelial lesion.

Table 2

Correlation between cytopathological results and presence of HPVs 16 and 18

\begin{tabular}{|c|c|c|c|c|c|c|c|c|c|c|c|}
\hline \multirow[t]{2}{*}{ Cytology } & \multicolumn{2}{|c|}{ HPV Negative } & \multicolumn{2}{|c|}{ HPV 16} & \multicolumn{2}{|c|}{ HPV 18} & \multicolumn{2}{|c|}{ HPV $X^{d}$} & \multicolumn{2}{|c|}{ Co-infection } & \multirow[t]{2}{*}{ Total } \\
\hline & $\mathrm{n}$ & $\%$ & $\mathrm{n}$ & $\%$ & $\mathrm{n}$ & $\%$ & $\mathrm{n}$ & $\%$ & $\mathrm{n}$ & $\%$ & \\
\hline Negative & 103 & 74.6 & 5 & 3.6 & 3 & 2.2 & 26 & 18.8 & 1 & 0.7 & 138 \\
\hline ASCUS/AGUS ${ }^{\mathrm{a}}$ & 1 & 11.1 & 2 & 22.2 & - & - & 6 & 66.7 & - & - & 9 \\
\hline LSIL $^{\mathrm{b}}$ & 1 & 6.7 & 3 & 20.0 & 1 & 6.7 & 10 & 66.7 & - & - & 15 \\
\hline HSIL $^{c}$ & - & - & 4 & 40.0 & - & - & 5 & 50.0 & 1 & 10.0 & 10 \\
\hline Invasive carcinoma & - & - & 1 & 50.0 & - & - & 1 & 50.0 & - & - & 2 \\
\hline Total & 105 & 60.3 & 15 & 8.6 & 4 & 2.3 & 48 & 27.6 & 2 & 1.1 & 174 \\
\hline
\end{tabular}

a: ASCUS/AGUS: Atypical squamous or glandular cells of undetermined significance; b: LSIL: Low grade squamous intraepithelial lesion; c: HSIL: High grade squamous intraepithelial lesion; d: HPV X: Viral type not determined.

samples and only HPV 16 and 18 have been investigated in the present study, it can be assumed that other HPV types were present in $50 \%$ of the samples with these cytopathological diagnostics.

\section{DISCUSSION}

HPV detection rates depend on the population studied, the method of detection, the type of specimen and how it is obtained. In the present study, the highest HPV detection rate was observed when the primer set GP5+/GP6+ was used. In 16 previously negative samples using MY9/MY11 primers and positive cytopathological results, 75\% (12/ 16) were positive when tested with GP5+/GP6+. In addition, of the 20 samples that were initially negative at both cytopathological and MY9/ MY11 PCR analysis, six were positive, when tested with GP5+/GP6+. Although the MY9/MY11 primer set has been extensively used for amplification of HPV genomic regions, the use of more than one consensus primers set increases the HPV detection rate in cervical samples ${ }^{5}$. The primer set GP5+/GP6+ includes a 3' end sequence modification of primers GP5/GP6 and was shown to increase HPV detection rates $^{23}$. In addition, it is likely that the amplification of a shorter genomic fragment by the primer set GP5+/GP6+ would be more efficient as compared to the longer DNA fragment amplified by MY9/ MY11 (150 pb versus $450 \mathrm{pb}$ ), improving sensitivity. It is worth noting that, although the occurrence of false positive PCR results may not be completely excluded in this analysis, the majority of the MY9/MY11 positive samples were also positive for GP5+/GP6+, HPV16 or HPV18 primer sets.

In this study HPV DNA was detected in $94.4 \%$ of the cytopathological positive samples. Moreover, it was observed that as the severity of the lesions increased, the detection rate for HPV infection increased, as well, and this finding is consistent with previous reports $^{5,18,26}$. Among the cytopathological negative samples, $25.4 \%$ presented HPV DNA. This frequency was higher than that observed by NONNENMACHER et al. ${ }^{20}$ which reported a HPV frequency of $13.8 \%$ among patients with cytopathological negative findings in a study performed at the city of Porto Alegre, Brazil. However, the HPV frequencies reported in Brazil may vary from $15 \%$ to $27 \%$ in studies conducted in health services for screening cervical cancer ${ }^{16,20}$.

Among the cases of LSIL, only 20\% presented HPV 16 and in $66.7 \%$ of the samples neither HPV16 nor HPV18 were detected (HPV$\mathrm{X})$. This result was similar to that found in another study performed in Brazil by LORENZATO et al. ${ }^{17}$ in which HPV 16 was detected in $19.4 \%$ $(12 / 62)$ of the samples diagnosed with NIC I in histopathological analysis. Four HPV 18 positive samples were observed, three were negative and one presented LSIL. Samples with LSIL diagnosis and HPV 18 have been reported by CAVALCANTI et al., as well ${ }^{7}$. On the other hand, cytopathological negative samples with HPV 18 might represent a latent infection by this virus. 


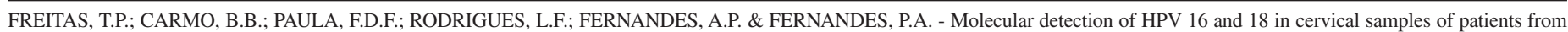
Belo Horizonte, Minas Gerais, Brazil. Rev. Inst. Med. trop. S. Paulo, 49(5): 297-301, 2007.

The HPV 16 detection rate was higher in the cases of HSIL and invasive carcinoma when compared to that found in ASCUS/AGUS or LSIL samples. GRCE et al., using the same HPV 16 and 18 specific primers sets, also observed that HPV 16 detection was higher in NIC III samples $(50 \%)$ in comparison to NIC I samples $(12.3 \%)^{13}$. Similarly, NINDL et al. observed in biopsy samples an increased HPV 16 detection from NIC I $(12.2 \%)$ to NIC III $(74 \%)^{19}$.

Two other studies were carried out in Belo Horizonte, Minas Gerais, aiming the identification of HPV infection by molecular methods ${ }^{2,27}$. BORGES et al. used the hybrid capture II method for HPV detection in negative and positive samples for squamous intraepithelial lesions $(\mathrm{n}=110)^{2}$. The detection rate for high risk oncogenic HPVs was $85 \%$ in samples with NIC II and NIC III, a detection rate higher than that observed in the present study (40\%). This difference could be partially explained by the fact that in the present study only two types of highrisk HPVs (16 and 18) were investigated, whereas the hybrid capture II method includes a pool of probes for searching 13 types of high risk oncogenic HPV, not allowing, however, the assessment of HPV types. Considering that in $50 \%$ of the samples with HSIL and invasive carcinoma the type of HPV was not determined, it is likely that these cases are associated to other types of high-risk HPVs.

SOUZA et al. searched for the presence of HPVs 6, 11, 16 18, 31, 33 and 35 by PCR with specific primers in ectocervical samples from HIV-positive patients $(\mathrm{n}=49)^{27}$. HPV infection was detected in 53\% (26/49) of the samples through histopathological analysis and in $85.7 \%$ (42/49) by PCR technique. High-risk HPVs were present in 15 out of 16 samples diagnosed with NIC I, II and III. This high rate of HPV detection in high-grade lesions (NIC II and III), as compared to the one detected in the present study, is probably associated to detection of other high-risk HPV types as well as to the population studied by these authors, since a higher prevalence of HPV infection is observed in HIV-positive patients9.

In this study additional information was presented regarding the frequency of HPV infection in an increased number of women from Belo Horizonte city, seen at secondary public health services. As expected, an increased HPV detection rate was detected as compared to those observed in previous studies performed in Brazil in samples obtained from patients seen at primary health services ${ }^{20}$. Thus, it is worth to emphasize, the need for assessment and comparison of such data. This information will certainly be useful to evaluate and to establish strategies for the prevention of cervical cancer, including the development, and later, the evaluation of vaccine efficacy.

\section{RESUMO}

\section{Detecção molecular de HPV 16 e 18 em amostras cervicais de pacientes de Belo Horizonte, Minas Gerais, Brasil}

Objetivos: $\mathrm{O}$ objetivo deste estudo foi investigar a frequiência da infecção por HPV e dos tipos 16 e 18 em amostras cervicais de pacientes atendidas em dois serviços públicos da cidade de Belo Horizonte-MG. Métodos: Amostras cervicais de 174 pacientes foram coletadas para estudo citopatológico e molecular. A pesquisa da infecção por HPV foi feita através da PCR utilizando os oligonucleotídeos MY09/MY11. Os tipos virais 16 e 18 foram pesquisados através da utilização de oligonucleotídeos específicos. Resultados: Dentre as 174 amostras analisadas, 20,7\% apresentaram lesões escamosas intra-epiteliais e/ ou invasoras detectadas na análise citopatológica, das quais $94,4 \%$ mostraram infecção por HPV. O HPV 16 foi encontrado em torno de $20 \%$ dos casos de lesão escamosa intra-epitelial de baixo grau e em $40 \%$ e $50 \%$ dos casos de lesão escamosa intra-epitelial de alto grau e carcinoma escamoso invasor, respectivamente. O HPV 18 foi encontrado em $6,7 \%$ das amostras com lesão de baixo grau e em dois casos de co-infecção com HPV 16. Em 50\% dos casos de lesão de alto grau, o tipo de HPV não foi determinado. Conclusões: O HPV 16 foi o tipo viral mais frequientemente detectado. No entanto, mais de $50 \%$ das amostras positivas no exame citopatológico não apresentaram HPV 16 e 18, indicando que possivelmente outros tipos virais estejam presentes em freqüências relativamente altas na população estudada.

\section{ACKNOWLEDGEMENTS}

The authors gratefully acknowledge Dr. Maria de Fátima Souza Brito, Dr. Vera Lúcia Lopes Furtado and Dr. Silvana Cló from Maternidade Odete Valadares de Belo Horizonte, MG and Dr. Túlio Cezar Alvim from Centro de Tratamento de Doenças Sexualmente Transmissíveis (CTDST) do Distrito Centro-Sul da Prefeitura de Belo Horizonte, MG, who collected the cervical samples for this study. The authors also acknowledge Maria do Carmo Moreira de Sousa for general supporting.

\section{REFERENCES}

1. BAUER, H.M.; TING, Y.; GREER, C.E. et al. - Genital human papillomavirus infection in female university students as determined by a PCR-based method. J. Amer. med. Ass., 265: 472-477, 1991.

2. BORGES, S.C.V.; MELO, V.H.; MORTOZA JÚNIOR, G. et al. - Taxa de detecção do papilomavírus humano pela captura híbrida II, em mulheres com neoplasia intraepitelial cervical. Rev. bras. Ginec. Obstet., 26: 105-110, 2004.

3. BOSCH, F.X.; MANOS, M.M.; MUNOZ, N. et al. - Prevalence of human papillomavirus in cervical cancer: a worldwide perspective. International biological study on cancer cervical (IBSCC) Study Group. J. nat. Cancer Inst., 87: 796-802, 1995.

4. BRASIL. Ministério da Saúde. Instituto Nacional do Câncer 2006. Available at: http:// www.inca.gov.br

5. CARRILlO, A.; MOHAR, A.; MENESES, A. et al. - Utilidad en la combinación de oligonucleótidos universales para la detección del vírus del papiloma humano en cáncer cervicouterino y lesiones premalignas. Salud publ. Méx., 46: 7-15, 2004.

6. CASTLE, P.E.; SOlOMON, D.; SCHIFFMAN, M. \& WHEELER, C.M. - Human papillomavirus type 16 infections and 2-year absolute risk of cervical precancer in women with equivocal or mild cytologic abnormalities. J. nat. Cancer Inst., 97: 1066-1071, 2005.

7. CAVALCANTI, S.M.B.; ZARDO, L.G.; PASSOS, M.R.L. \& OLIVEIRA, L.H.S. Epidemiological aspects of human papillomavirus infection and cervical cancer in Brazil. J. Infect., 40: 80-87, 2000 .

8. CUSCHIERI, K.S.; CUBIE, H.A.; WHITLEY, M.W. et al. - Multiple high risk HPV infections are common in cervical neoplasia and young women in a cervical screening population. J. clin. Path., 57: 68-72, 2004.

9. DUERR, A.; KIERE, B.; WARREN, D. et al. - Human papillomavirus-associated cervical cytological abnormalities among women with or at risk of infection with human immunodeficiency virus. Amer. J. Obstet. Gynec., 184: 584-590, 2001. 


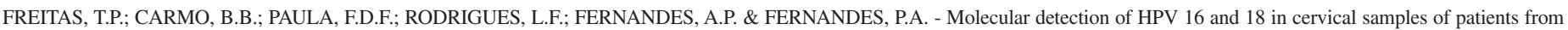
Belo Horizonte, Minas Gerais, Brazil. Rev. Inst. Med. trop. S. Paulo, 49(5): 297-301, 2007.

10. ELUF-NETO, J.; BOOTH, M.; MUNOZ, N. et al. - Human papillomavirus and invasive cervical cancer in Brazil. Brit. J. Cancer, 69: 114-119, 1994.

11. FERENCZY, A. \& FRANCO, E. - Persistent human papillomavirus infection and cervical neoplasia. Lancet Oncol., 3: 11-16, 2002.

12. GONÇALVES, M.A.; MASSAD, E.; BURATTINI, M.N. \& VILLA, L.L. - Relationship between human papillomavirus (HPV) genotyping and genital neoplasia in HIVpositive patients of Santos City, São Paulo, Brazil. Int. J. STD AIDS, 10: 803-807, 1999.

13. GRCE, M.; HUSNJAK, K.; MAGDIC, L. et al. - Detection and typing of human papillomaviruses by polymerase chain reaction in cervical scrapes of Croatian women with abnormal cytology. Europ. J. Epidem., 13: 645-651, 1997.

14. KHAN, M.J.; CASTLE, P.E.; LORINCZ, A.T. et al. - The elevated 10-year risk of cervical precancer and cancer in women with human papillomavirus (HPV) type 16 or 18 and the possible utility of type-specific HPV testing in clinical practice. J. nat. Cancer Inst., 97: 1072-1079, 2005.

15. KOUTSKY, L. - Epidemiology of genital human papillomavirus infection. Amer. J. Med., 102: 3-8, 1997.

16. LIMA SOARES, V.; MESQUITA, A.M.; CAVALCANTE, F.G. et al. - Sexually transmitted infection in a female population in rural north-east Brazil: prevalence, morbidity and risk factors. Trop. Med. Int. Hith, 8: 595-603, 2003.

17. LORENZATO, F.; HO, L.; TERRY, G. et al. - The use of human papillomavirus typing in detection of cervical neoplasia in Recife (Brazil). Int. J. Gynec. Cancer, 10: 143 $150,2000$.

18. MUÑOZ, N. - Human papillomavirus and cancer: the epidemiological evidence. J. clin. Virol., 19: 1-5, 2000

19. NINDL, I.; LOTZ, B.; KUHNE-HEID, R.; ENDISCH, U. \& SCHNEIDER, A. Distribution of 14 high risk HPV types in cervical intraepithelial neoplasia detected by a non-radioactive general primer PCR mediated enzyme immunoassay. J. clin. Path., 52: 17-22, 1999.

20. NONNENMACHER, B.; BREITENBACH, V.; VILLA, L.L.; PROLLA, J.C. \& BOZZETTI, M.C. - Identificação do papilomavírus humano por biologia molecular em mulheres assintomáticas. Rev. Saude publ. (S. Paulo), 36: 95-100, 2002.
21. NORONHA, V.; MELLO, W.; VILLA, L.L. et al. - Human papillomavirus associated with uterine cervix lesions. Rev. Soc. bras. Med. trop., 32: 235-240, 1999.

22. RABELO-SANTOS, S.H.; ZEFERINO, L.; VILLA, L.L. et al. - Human papillomavirus prevalence among women with cervical intraepithelial neoplasia III and invasive cervical cancer from Goiânia, Brazil. Mem. Inst. Oswaldo Cruz, 98: 181-184, 2003.

23. RODA HUSMAN, A.M.; WALBOOMERS, J.M.; VAN DEN BRULE, A.J.; MEIJER, C.J. \& SNIJDERS, P.J. - The use of general primers GP5 and GP6 elongated at their 3' ends with adjacent highly conserved sequences improves human papillomavirus detection by PCR. J. gen. Virol., 76: 1057-1062, 1995.

24. ROSENBLATT, C.; LUCON, A.M.; PEREYRA, E.A.G. et al. - HPV prevalence among partners of women with cervical intraepithelial neoplasia. Int. J. Gynec. Obstet. 84: 156-161, 2004

25. SAIKI, R.K.; GELFAND, D.H.; STOFFEL, S. et al. - Primer-directed enzymatic amplification of DNA with a thermostable DNA polymerase. Science, 239: 487 $491,1988$.

26. SCHIFFMAN, M. \& CASTLE, P.E. - Human papillomavirus: epidemiology and public health. Arch. Path. Lab. Med., 127: 930-934, 2003.

27. SOUZA, N.S.T.; MELO, V.H. \& CASTRO, L.P.F. - Diagnóstico da infecção pelo HPV em lesões do colo do útero em mulheres HIV+: acuidade da histopatologia. Rev. bras. Ginec. Obstet., 23: 355-364, 2001

28. TJALMA, W.A.A.; VAN WAES, T.R.; VAN DEN EEDEN, L.E. \& BOGERS, J.J.P.M. Role of human papillomavirus in the carcinogenesis of squamous cell carcinoma and adenocarcinoma of the cervix. Best Pract. Res. clin. Obstet. Gynaec., 4: 469483, 2005 .

29. VILLA, L.L.; CABALLERO, O.L.; LEVI, J.E.; PENA, S.D. \& SIMPSON, A.J. - An approach to human papillomavirus identification using low stringency single specific primer PCR. Molec. Cell. Probes, 9: 45-48, 1995.

Received: 29 May 2006

Accepted: 22 May 2007 